\title{
CSF MARKERS FOR DIAGNOSIS OF BACTERIAL MENINGITIS IN NEUROSURGICAL POSTOPERATIVE PATIENTS
}

\author{
Wagner Malagó Tavares', Andre Guelman Machado², \\ Hamilton Matushita², Jose Pindaro P. Plese ${ }^{2}$
}

\begin{abstract}
Objective: To evaluate the diagnostic usefulness of cerebral spinal fluid (CSF) cellularity, protein, neutrophils, glucose and lactate for detection of postoperative bacterial meningitis. Method: This p rospective study was conducted in 28 postoperative neurosurgical patients from 2002 to 2005 at University of São Paulo. The CSF markers were plotted in a receiver operating characteristic (ROC) curve to evaluate their accuracy. Results: Based on the area under ROC curve CSF glucose, cellularity, and lactate were conside red good tests. Polymorphonuclear and protein did not achieve enough accuracy to be used clinically. Conclusion: The CSF glucose, lactate, and cellularity can be used for the diagnosis of bacterial meningitis. Moreover, it can be helpful to differentiate bacterial from aseptic meningitis.
\end{abstract}

KEY WORDS: CSF, bacterial meningitis, neurosurgery, ROC analysis, postoperative infection.

\begin{abstract}
Marcadores liquóricos para o diagnóstico de meningite bacteriana em pós-operatório neurocirúrgico

RESUMO - Objetivo: Para avaliar a utilidade diagnóstica dos marc a d o res liquóricos de celularidade, concentração de proteína, neutrofilia, concentração de glicose e lactato para a detecção da meningitie bacteriana no pós-operatório neurocirúrgico. Método: Esse estudo foi conduzido de maneira prospectiva na Universidade de São Paulo no período de 2002 a 2005 em 28 pacientes no pós-operatório neurocirúrgico. Os marc a d o res liquóricos foram colocados em uma curva ROC (receiver operating characteristic) para avalição da sua acurácia. Resultados: Baseadas na área sob a curva ROC, glicorraquia, celularidade e concentração de lactato foram considerados bons testes. A contagem de polimorfonucleares e a proteínorraquia não atingiram acurácia suficiente para serem utilizadas clinicamente. Conclusão: A glicorraquia, a concentração de lactato e a celularidade podem ser utilizadas clinicamente para o diagnóstico da meningite bacteriana. Esses marc a d o res também podem ser úteis na diferenciação entre meningite bacteriana e asséptica.
\end{abstract}

PALAVRAS-CHAVE: meningite bacteriana, LCR, neurocirurgia, curva ROC, infecção pós-operatória.

Postoperative meningitis is an uncommon complication $(0.3 \text { to } 1.5 \%)^{1}$ following intradural proce$\mathrm{d} u$ re, and is potentially fatal with mortality of 20 to $50 \%{ }^{2}$. The diagnosis of meningitis in postsurgical patients is often difficult especially if the patient has been subjected to a ventricular or posterior fossa procedure. The clinical signs of fever, meningismus and mental status alteration are non-specific and insufficient for the diagnosis of postoperative meningitis $^{3}$.

Analysis of cerebral spinal fluid (CSF) can be helpful in many cases. However, postoperative CSF markers including lactate, glucose, protein and cellularity can also differ because of brain manipulation, un- derlying brain pathology or bleeding into CSF following intradural procedure ${ }^{4-6}$. The desirability of avoiding unnecessary administration of antibiotics to noninfected patients, the potentially devastating consequences associated with administration of corticoste roids to patients with aseptic meningitis, and the need to establish diagnostic usefulness of CSF markers have prompted this study.

\section{METHOD}

Patients - Lumbar or external ventricular CSF samples were obtained from 28 postoperative patients. This study was approved by the University of São Paulo ethics committee and no patient had a sample taken just for purpos-

Division of Neurosurgery - University of São Paulo Medical School - São Paulo SP, Brazil: ${ }^{1} \mathrm{MD} ;{ }^{2} \mathrm{MD}, \mathrm{PhD}$.

Received 25 October 2005, received in final form 27 January 2006. Accepted 6 April 2006.

Dr. Wagner Malagó Tavares - Rua Alves Guimarães 642 / 125 - 05410-001 São Paulo SP - Brasil. E-mail: wagnermt@hotmail.com 
es of this study. Patients had at least one clinical manifestation of bacterial meningitis (BM) including fever, meningismus and alteration of mental status. The group comprised 9 females and 19 males; mean age was 41 years (range 2 to 69 years old). Samples were collected between days 1 to 21 after initial intradural procedure.

Sample collection and analysis - We first rinsed the ext e rnal ventricular derivation (EVD) for 10 minutes with iodide povidine. CSF was collected into sterile polystyrene tubes and immediately submitted for analysis. Assessment of CSF markers CSF glucose and lactate were determined using Roche ${ }^{\mathrm{TM}}$ kit with Hitachi equipment. Total CSF protein was determined in Hitachi equipment using the benzethonium chloride precipitation technique standardized to the biuret method. Cell counts were determined using a calibrated Fuchs-Rosenthal chamber after staining with toluidine blue. CSF analysis to distinguish polymorphonuclear leukocytes (PMNs) and lymphocytes was done using Shandon cytocentrifuge and Pappenheim stain.

Statistical analysis - Statistical analyses were performed with SPSSTM for Windows. The CSF markers were analyzed to determine specificity and sensitivity of each marker and combinations between them. We used the Receiver Operating Characteri stic (ROC) curve to evaluate clinical usefulness of each marker. The ROC curve represents the probability of true results in a disease as a function of the prob- ability of false positive results of a test. The area under the curve re presents the validity of a test with 1.00 being the highest and 0 the lowest. A classification for accuracy of a diagnostic test considers .90 to $1.00=$ excellent; .80 to $.89=$ good; .70 to $.79=$ fair; .60 to $.69=$ poor; .50 to $.59=$ failure.

\section{RESULTS}

Of 28 patients, 7 had positive Gram stain and culture for bacteria. Table 1 presents the types of operations and bacteria involved in the infection. We summarized the CSF markers according to highest ROC under the curve, sensitivity, specificity and predictive value (Table 2). The aforementioned values and the cutoff values were based on the point of the ROC curve which presented highest sensitivity and specificity. Markers were classified according to area under the curve as excellent, good, fair, poor and failure as defined under methods. Based on these criteria, glucose, lactate, and cellularity were classified as good tests. Number of PMNs was classified as fair and and p rotein as poor. No tests achieved the excellent classification.

Table 3 describes the ROC analysis of CSF markers with their respective confidence intervals. All of the tests presented an excellent specificity $(90.5 \%)$ but

Table 1. Types of procedure and the nature of infection.

\begin{tabular}{ll}
\hline Operation & Bacteria \\
\hline Parietal glioma & Staphylococcus aureus \\
Convexity meningioma & Streptococcus epidermidis \\
Ophthalmic artery aneurysm & Acinetobacter baumanii \\
Intradural correction of traumatic fistula & Enterobacter cloacae \\
Lobar hematoma drainage & Klebsiella pneumoniae \\
Occipital encephalocele correction & Enterococcus faecalis \\
Posterior fossa craniectomy & Staphylococcus aureus \\
\hline
\end{tabular}

Table 2. CSF markers diagnostic power.

\begin{tabular}{lcccccc}
\hline CSF markers & Cutoff* & Area under & Sensitivity & Specificity & $\begin{array}{c}\text { Positive } \\
\text { predictive } \\
\text { value }\end{array}$ & $\begin{array}{c}\text { Negative } \\
\text { predictive } \\
\text { value }\end{array}$ \\
\hline Glucose & $30 \mathrm{mg} / \mathrm{dL}$ & .884 & $86 \%$ & $90.5 \%$ & $75 \%$ & $95 \%$ \\
Cellularity & $768 / \mathrm{mL}$ & .854 & $71.4 \%$ & $90.5 \%$ & $83 \%$ & $91 \%$ \\
Lactate & $49 \mathrm{mg} / \mathrm{dL}$ & .850 & $86 \%$ & $90.5 \%$ & $75 \%$ & $95 \%$ \\
Polymorphonuclear & $575 / \mathrm{mL}$ & .789 & $42.9 \%$ & $90.5 \%$ & $50 \%$ & $67 \%$ \\
Protein & $370.5 \mathrm{mg} / \mathrm{dL}$ & .663 & $28.6 \%$ & $90.5 \%$ & $25 \%$ & $79 \%$ \\
\hline
\end{tabular}

*The cutoff values were chosen based on the highest sensitivity and specificity on ROC curve. 
Table 3. Area under the curve and their respective confidence intervals.

\begin{tabular}{lccccc}
\hline CSF test result & Area & $\begin{array}{c}\text { Std. } \\
\text { variable(s) }\end{array}$ & $\begin{array}{c}\text { Asymptotic } \\
\text { Error }\end{array}$ & \multicolumn{2}{c}{ Asymptotic 95\% confidence interval } \\
\cline { 5 - 6 } Glucose & .884 & .096 & .003 & Lower bound & Upper bound \\
Cells & .854 & .090 & .006 & .696 & 1.073 \\
PMN & .789 & .102 & .024 & .678 & 1.029 \\
Lactate & .850 & .113 & .006 & .628 & .989 \\
Protein & .663 & .108 & .203 & .452 & 1.073 \\
\hline
\end{tabular}

ander the nonparametric assumption; b Null hypothesis: true area $=0.5$.

a poor sensitivity with the exception of lactate and glucose $(86 \%)$. In order to improve sensitivity we changed the cutoff values for all markers but this change decreased specificity to unacceptable levels $(<70 \%)$. We found high predictive levels for glucose and lactate (positive predictive value $75 \%$, negative predictive value $95 \%$ ) and also cellularity (positive predictive value $83 \%$, negative predictive value $91 \%$ ).

All the marker values were statistically significant with $95 \%$ confidence.

\section{DISCUSSION}

The postoperative period after neurosurgery may be complicated by non-frequent but life-threatening $\mathrm{BM}^{7-9}$. Neurosurgical patients frequently have ventricular drains, bladder and intravenous catheters that may be present for a long time. All of these factors together with type and duration of the operation can increase the chance of infection after neurosurgery. The onset of BM may be insidious and difficult to diff e rentiate from the onset of other infections that cause similar symptoms. Moreover, postoperative changes caused by opening of the meninges and breakdown of blood products may contribute to the clinical picture of fever, confusion and meningismus sometimes observed after neurosurgery. Clinical features are not reliable to diffe rentiate between $\mathrm{BM}$ and aseptic meningitis ${ }^{3}$. Therefore, diagnosis of $\mathrm{BM}$ can be made solely by detection of bacteria on Gram stain or isolation in culture, but CSF cultures remain negative in $70 \%$ of clinically suspected cas$\mathrm{es}^{7}$. The sensitivity and specificity of bacterial isolation from CSF can be raised if gene amplification is performed on the specimen ${ }^{10}$. This technique requires trained personnel and equipment not available in many clinical laboratories perfo rming studies on CSF.

BM necessitates prompt and early diagnosis because of its devastating consequences ${ }^{8}$. Use of bro ad spectrum antibiotics is to be avoided because of high cost and risk to unaffected patients ${ }^{2,3}$. Moreover, the use of intravenous antibiotics and corticosteroids in suspected cases of postoperative BM impairs the diagnostic value of CSF markers ${ }^{2}$. Our present study analyzes postoperative CSF to establish cutoff values for cellularity, lactate, glucose, protein, and PMNs for the diagnosis of BM.

Cortes-Lopez et al. ${ }^{11}$ found a sensitivity of $51.5 \%$ and specificity of $95 \%$ using CSF leukocyte count of $\geq 1700 / \mathrm{mL}$. Using this cutoff we had a similar result of $57.1 \%$ and $100 \%$, respectively, but this cutoff did not represent the spot on the ROC curve with highest sensitivity and specificity. We lowered the cutoff value to 768 cells $/ \mathrm{mL}$ and found a sensitivity o $71.4 \%$ and specificity of $90.5 \%$. Cortes-Lopez et al. ${ }^{11}$ argued that the CSF number of PMNs, protein concentration and glucose were not diff e rent enough to discriminate. We agree in part, since we found a high are a under the ROC curve, as well as high sensitivity and specificity for lactate and glucose. The number of PMNs and protein concentration were not classified as good tests for the diagnosis of BM. Lactate analysis in this study has inferior sensitivity and specificity compared to previous work ( 88 and $98 \%$ respectively) ${ }^{2}$. Results of this study were also different from those published by Ross et al. ${ }^{3}$. Reported differences in the diagnostic power of CSF markers could be explained by: 1) the type of study design ( retrospective studies are more susceptible to bias related to data and population selection); 2) use of antibiotics and steroid which may decrease inflammation and CSF culture growth thus lowering the diagnostic value of CSF analysis; 3 ) prevalence of BM in the study $g$ roup which correlates directly with diagnostic power of the tests under evaluation. In this study the prevalance of BM was $25 \%$, close to the value in other studies $^{2,3,10}$.

One may argue that in cases of BM the number of neutrophils could raise the concentration of lac- 
tate in CSF. However, several authors in clinical, in vitro and animal studies did not find a significant p roduction of lactate by neutrophils ${ }^{12-14}$. Moreover, CSF lactate level is not affected by the presence of red blood cells and it can be used in postoperative neurosurgical patients ${ }^{2,15,16}$.

All patients in our study received antibiotics and steroids as soon as BM was suspected. As already mentioned, this use can lower the diagnostic power of CSF markers. As shown by Salord et al. ${ }^{10}$, sensitivity and specificity of CSF markers and hence the prevalence of BM can be increased if PCR and gene amplification techniques are applied to CSF samples. Use of $D(-)$ lactate, tumor necrosis factor $\beta$, interleukin$1 \beta$, interleukin- 6 and interleukin- 8 can also incre ase sensitivity and specificity ${ }^{1,11}$ but these assays are not readily available in clinical laboratories receiving CSF for diagnostic testing. Assays for the CSF markers evaluated in this study are relatively inexpensive, rapid and established in most laboratories.

Our current results show that for postoperative neurosurgical patients, CSF cellularity, glucose and lactate can be more reliable for the diagnosis of BM than clinical parameters alone. These CSF markers are available routinely in clinical laboratories, however, if there is still doubt about the diagnosis, empirical treatment should be started ${ }^{17}$.

Acknowledgements - To Jean H. Priest (retaired professor of the Emory University, Atlanta USA) for helping the translation of this paper.

\section{REFERENCES}

1. Salord F, Boussaid O, Eynard N, Perret C, Grando J, Chacornac R. Interet du dosage du $\mathrm{D}(-)$ lactate pour le diagnostic rapide de meningite après craniotomie: étude preliminaire Ann Fr Anesth Reanim 1994;13: 647- 653.

2. Leib SL, Boscacci R, Gratzl O, Zimmerli W. Predictive value of cerebrospinal fluid (CSF) lactate level versus CSF/Blood glucose ratio for the diagnosis of bacterial meningitis following neurosurgery. Clin Inf Dis 1999;29:69-74.

3. Ross D, Rosegay H, Pons V. Diffe rentiation of aseptic and bacterial meningitis in postoperative neuro s u rgical patients. J Neuro su rg 1988; 69:669-674.

4. Carmel PW, Fraser RAR, Stein BM. Aseptic meningitis following posterior fossa surgery in children. J Neurosurg 1974;41:44-49.

5. Kaufman BA, Tunkel, AR, Pryor JC, et al. Meningitis in the neurosurgical patient. Infect Dis Clin N Am 1990;4:677-701.

6. Kim YS, Pons VG. Infectious in the neurosurgical intensive care unit. Neurosurg Clin N Am 1994;5:741-754.

7. Blomstedt GC. Infections in neuro su rgery: a re st rospective study of 1143 patients and 1517 operations. Acta Neurochir (Wien) 1985;78: 81-90.

8. Buckwold FJ, Hand R, Hansebout RR. Hospital-acquired bacterial meningitis in neurosurgical patients. J Neurosurg 1977;46:494-500.

9. Mollman HD, Haines SJ. Risk factors for postoperative neurosurgical wound infection: a case-control study. J Neurosurg 1986;64:902-906.

10. SalordF, Druel B, Grando J, et al. Aseptic meningitis: demonstration of bacterial DNA in cerebrospinal fluid by gene amplification. Ann Fr Anesth Reanim 1995;14:320-325.

11. Lopez-Cortes LF, Marquez-Arbizu R, Jimenez-Jimenez LM, et al. Cerebrospinal fluid tumor necrosis factor- $\beta$, interleukin- $1 \beta$, interleukin6 , and interleukin-8 as diagnostic markers of cerebrospinal fluid infection in neurosurgical patients. Crit Care Med 2000;28:215-219.

12. Bland, RD, Lister RC, Ries JP. Cerebrospinal fluid lactic acid level and $\mathrm{pH}$ in meningitis: aids in diff e rential diagnosis. Am J Dis Child 1974; 128:151-156.

13. Guerra-RomeroL, Tauber MG, Fournier MA, Tu reen JH. Lactate and glucose concentrations in brain interstitial fluid, cereb rospinal fluid, and serum during experimental pneumococcal meningitis. J Infect Dis 1992;166:546-550.

14. Tauber MG, Borschberg U, Sande MA. Influence of granulocytes on brain edema, intracranial pressure, and cere $b$ rospinal fluid concentrations of lactate and protein in experimental meningitis. J Infect Dis 1998; 157:456-464.

15. Begovac J, Bace A, Soldo I, Lehpamer B. Lactate and glucose in cereb rospinal fluid heavily contaminated with blood. Acta Med Croatica 1991;45:341-345.

16. Cameron PD, Boyce JM, Ansari BM. Cere b rospinal fluid lactate in meningitis and meningococcaemia. J Infectol 1993;26:245-252.

17. Martins R, Ciquini O Jr, Matushita H, Cabral ND, Plese JPP. Infections of cereb rospinal fluid shunts in children: review of 100 infections in 87 children. Arq Neuropsiquiatr 1997;55:75-81. 